\title{
PEMBINAAN CIVIC DISPOSITION BERBASIS NILAI-NILAI KEMANUSIAAN PADA PEMBELAJARAN PENDIDIKAN KEWARGANEGARAAN DI SEKOLAH TINGGI ILMU KESEHATAN KOTA SUKABUMI
}

\author{
Fusnika, Prodi Pendidikan Kewarganegaraan, SPs, UPI, email: fusnika@yahoo.co.id
}

\begin{abstract}
ABSTRAK
Sekarang ini nilai-nilai kemanusiaan pada dunia medis sudah merosot dengan indikator begitu banyak kasus-kasus pelanggaran hak asasi terhadap pasien dan dalam lingkungan rumah sakit banyak dijumpai tenaga keperawatan yang kurang beretika. Pada dunia keperawatan nilai - nilai kemanusiaan sangatlah penting karena nilai kemanusiaan merupakan suatu sikap dan pendekatan yang memperlakukan pasien sebagai manusia yang mempunyai kebutuhan lebih dari sekedar nomor tempat tidur atau sebagai seorang berpenyakit tertentu. Perawat harus menggunakan pendekatan humanistik dalam prakteknya untuk memperhitungkan semua yang diketahuinya tentang pasien yang meliputi pikiran, perasaan, nilai-nilai, pengalaman, kesukaan, dan bahasa tubuh pasien. Mahasiswa keperawatan sebagai bagian dari masyarakat mendapatkan Pendidikan Kewarganegaran di Perguruan Tinggi dalam rangka mempersiapkan mereka agar dapat lebih baik ketika menjadi tenaga medis nantinya dengan memiliki watak-watak kewarganegaraan yang baik.
\end{abstract}

Kata kunci: civic disposition, nilai kemanusiaan, pembelajaran PKn.

\section{PENDAHULUAN}

Berbicara tentang nilai kemanusiaan berarti berbicara tentang beberapa aspek yang memiliki pengertian yang saling berkaitan, di antaranya mengenai humanisme, etika, kebudayaan dan perilaku. Humanisme sendiri adalah aliran yang bertujuan menghidupkan rasa perikemanusiaan atau mencita-citakan pergaulan yang lebih baik. Ada juga yang berpendapat humanisme sebagai sikap atau tingkah laku mengenai perhatian manusia dengan menekankan pada rasa belas kasih serta martabat individu.

Etika dalam keperawatan merupakan prinsip-prinsip mengenai tingkah laku profesional yang tepat berkaitan dengan hak dirinya sebagai tenaga medis, hak pasiennya, hak teman sejawatnya maupun hak orang lain. Bila dikaitkan dengan kebudayaan, perawat adalah suatu profesi yang berhubungan langsung dengan manusia sebagai lawan interaksinya dalam konteks makhluk yang sama berbudaya. Karena itu seorang perawat harus mengetahui segala hal yang berkaitan dengan manusia, baik sebagai individu maupun sebagai makhluk sosial. Untuk membangun nilai-nilai sosial itu agar tetap menjadi landasan bagi setiap perawat dalam menjalani kehidupan profesinya yang luas.

Nilai-nilai kemanusiaan ini diharapkan bisa diterapkan dalam praktek keperawatan, pelayanan kesehatan dan pendidikan keperawatan, bisa memberi pelayanan optimal kepada masyarakat tanpa adanya penyimpangan-penyimpangan ataupun penyalahgunaan ilmu-ilmu keperawatan untuk hal-hal yang melanggar nilai-nilai kemanusiaan. Perawat merupakan aspek penting dalam pembangunan kesehatan. Perawat merupakan salah satu tenaga kesehatan yang diatur dalam PP No. 32 Tahun 1996 tentang Tenaga Kesehatan. Bahkan dalam penyelenggaraan pelayanan kesehatan, tenaga perawat merupakan jenis tenaga kesehatan terbesar yang dalam kesehariannya selalu berhubungan langsung dengan pasien dan tenaga kesehatan lainnya. Namun di dalam menjalankan tugasnya tak jarang perawat bersinggungan dengan masalah hukum. Bahkan 
profesi perawat sangat rentan dengan kasus hukum seperti gugatan malpraktik sebagai akibat kesalahan yang dilakukannya dalam pelayanan kesehatan.

Menurut Dwidiyanti (2008:5) dalam keperawatan, humanisme merupakan suatu sikap dan pendekatan yang memperlakukan pasien sebagai manusia yang mempunyai kebutuhan lebih dari sekedar nomor tempat tidur atau sebagai seorang berpenyakit tertentu. Perawat yang menggunakan pendekatan humanistik dalam prakteknya memperhitungkan semua yang diketahuinya tentang pasien yang meliputi pikiran, perasaan, nilai-nilai, pengalaman, kesukaan, dan bahasa tubuh.

Dalam Undang-Undang Dasar Negara Republik Indonesia Tahun 1945, Kesehatan merupakan hak asasi manusia dan salah satu unsur kesejahteraan yang harus diwujudkan sesuai dengan cita-cita bangsa Indonesia. Begitulah bunyi salah satu kalimat dalam Undang-Undang Republik Indonesia No 36 tahun 2009 tentang kesehatan. Bahwa kesehatan adalah hak asasi manusia, dan seperti yang kita ketahui, hak asasi itu harus ditunaikan. Tidak peduli seseorang kaya atau miskin pejabat atau rakyat biasa, semua warga negara berhak sehat.

Kenyataan di lapangan masih banyak keluhan dari masyarakat atau pasien terhadap kualitas pelayanan perawat di rumah sakit. Salah satu hal yang banyak disorot adalah masalah tingkah laku perawat seperti tidak ramah, kurang senyum dan tidak segera datang bila dipanggil dalam melayani pasien. Dan sering di jumpai seorang perawat yang berperilaku kasar dan emosional dalam memeriksa pasien sehingga menimbulkan kesan tidak baik. Kemampuan perawat dalam menangani pasien secara cepat dan tepat tanpa memandang status sosial ekonomi pasien. Hal ini penting karena perawat terkadang terlalu prosedural sehingga pasien tidak tertangani secara baik.

Oleh karena itu dibutuhkan suatu sikap yang profesional dalam diri perawat. Untuk melahirkan perawat-perawat profesional diperlukan suatu sistem pendidikan yang bemutu, yang berorentasi pada perkembangan ilmu pengetahuan dan kebutuhan masyarakat. Sistem pendidikan sebaiknya dapat melahirkan perawat profesional, yang tidak hanya memiliki kemam- puan intelektual, tetapi juga memiliki kemampuan dalam hal emosional, spritual dan psikomotor. Oleh karena itu dalam proses pendidikan keperawatan harus memperhatikan input, proses, output atau outcome dari proses pendidikan. Dengan pengetahuan dan pemahaman tersebut diharapkan dapat terinternalisasi dalam diri mahasiswa keperawatan. Tujuan dari pendidikan kewarganegaraan yang diberikan di Perguruan Tinggi bertujuan untuk mengajarkan mahasiswa untuk berkarakter kuat layaknya sila-sila dalam pancasila yang mengutamakan Tuhan yang Maha Esa dalam bertindak. Pendidikan Kewarganegaraan mengajarkan bagaimana warga negara itu tidak hanya tunduk dan patuh terhadap negara, tetapi juga mengajarkan bagaimana sesungguhnya warga negara itu harus toleran dan mandiri.

Pendidikan kewarganegaraan di perguruan tinggi merupakan sumber nilai dan pedoman dalam mengembangkan dan penyelenggaraan program studi, guna mengantarkan mahasiswa memantapkan kepribadiannya sebagai manusia seutuhnya. Hal ini berdasarkan pada suatu realitas yang dihadapi, bahwa mahasiswa adalah sebagai generasi bangsa yang harus memiliki visi intelektual, religious, berkeadaban, berkemanusiaan dan cinta tanah air dan bangsanya. pendidikan kewarganegaraan di perguruan tinggi adalah untuk membantu mahasiswa memantapkan kepribadiannya, agar secara konsisten mampu mewujudkan nilai-nilai dasar Pancasila, rasa kebangsaan dan cinta tanah air dalam menguasai, menerapkan dan mengembangkan ilmu pengetahuan, teknologi dan seni dengan rasa tanggung jawab dan bermoral.

\section{Watak Kewaragnegaran (civic Disposition) Pada Pembelajaran PKn}

Pendidikan Kewarganegaraan (PKn) sebagai bagian dari mata pelajaran yang diberikan kepada mahasiswa ikut berperan besar dalam mewujudkan tujuan pendidikan nasional. PKn merupakan salah satu instrumen fundamental dalam bingkai pendidikan nasional sebagai media bagi pembentukan karakter bangsa (nation and character building) di tengah heterogenitas atau pluralisme yang menjadi karakteristik utama bangsa Indonesia. 
Pendidikan Kewarganegaraan bertujuan untuk mendidik peserta didik agar menjadi warga negara yang baik (good citizen). Warga negara yang baik memiliki tiga kemampuan kewarganegaraan meliputi: pengetahuan kewarganegaraan (civic knowledge), keterampilan kewarganegaraan (civic skills), dan karakter kewarganegaraan (civic disposition). Agar tujuan PKn dapat tercapai, perlu dikembangkan strategi pembelajaran yang dapat mengembangkan ketiga kemampuan kewarganegaraan tersebut. Salah satu strategi yang dapat dipilih adalah dengan mengembangkan strategi pembelajaran kewarganegaraan berbasis kearifan lokal. Nilai-nilai kearifan lokal memiliki peran strategis dalam pembentukan karakter dan identitas bangsa. Pendidikan kewarganegaraan yang dikembangkan dengan memanfaatkan kearifan lokal akan bermuara pada munculnya sikap yang mandiri, penuh inisiatif, dan kreatif. Secara paradigmatik (Winataputra, 2001: 74), mengemukakan bahwa Pendidikan Kewarganegaraan memiliki tiga komponen, yakni : (1) kajian ilmiah pendidikan ilmu kewarganegaraan; (2) program kurikuler Pendidikan Kewarganegaraan; dan (3) gerakan sosial-kultural kewarganegaraan, yang secara koheren bertolak dari esensi dan bermuara pada upaya pengembangan pengetahuan kewarganegaraan (civic knowledge), nilai, sikap dan watak kewarganegaraan (civic disposition), dan keterampilan kewarganegaraan (civic skill).

Watak kewarganegaraan (civic dispositions), merupakan sifat - sifat yang harus dimiliki setiap warga negara untuk mendukung efektivitas partisipasi politik, berfungsinya sistem politik yang sehat, berkembangnya martabat dan harga diri dan kepentingan umum. Watak Kewarganegaraan (civic disposition) dimaksud oleh Quigley, dkk (1991:11) adalah "...those attitudes and habit of mind of the citizen that are conducive to the healthy functioning and common good of the democratic system" atau sikap dan kebiasaan berpikir warga negara yang menopang berkembangnya fungsi sosial yang sehat dan jaminan kepentingan umum dari sistem demokrasi. Secara konseptual, civic dipsosition mencakup sejumlah karakteristik kepribadian menurut Quigley, dkk (1991:13-14), yakni “civility (respect and civil discourse), individual responsibility, selfdiscipline, civic-mindedness, open-mindedness (openness, skepticism, recognition of ambigity), compromise (conflict of principles, compassion, generosity, and loyalty to the nation and its principles.

Maksud semua itu adalah kesopanan yang mencakup penghormatan dan interaksi manusiawi, tanggung jawab individual, disiplin diri, kepedulian terhadap masyarakat, keterbukaan pikiran yang mencakup keterbukaan, skeptisisme, pengenalan terhadap kemenduaan, sikap kompromi yang mencakup prinsip-prinsip konflik dan batas-batas kompromi, toleransi pada keragaman, kesabaran, keharuan, kemurahan hati, dan kesetiaan terhadap bangsa dan segala prinsipnya.

Pentingnya watak kewarganegaraan ini jarang sekali ditegaskan. Karakter publik dan privat yang mendasari demokrasi, dalam jangka panjang, mungkin lebih merupakan dampak dari pengetahuan atau kecakapan yang dikuasai warga negara. Hakim Learned Hand dalam pidatonya di New York pada tahun 1994 mengungkapkan pentingnya watak kewarganegaraan dalam kata-kata yang sekarang menjadi amat popular, memurut Bronson (1998:12) : "Liberty lies in the hearts of men and women; when it dies there, no constitution, no law, no court can save it; no constitution, no law, no court can even do much to help it. While it lies there, it needs no constitution, no law, no court to save it". Artinya, kebebasan terletak pada hati manusia, baik pria maupun wanita. Bila ia sirna maka tak ada konstitusi, hukum, dan pengadilan yang dapat menyelamatkan. Bahkan konstitusi, hukum, dan pengadilan tak dapat berbuat apa-apa. Namun bila ia masih di sana, maka tak diperlukan lagi konstitusi, hukum, dan pengadilan untuk menjaganya.

Bagaimana lazimnya suatu bidang studi yang diajarkan, materi Pendidikan Kewarganegaraan menurut Branson (1999:4) harus mencakup tiga komponen, yaitu "Civic Knowledge (pengetahuan Kewarganegaraan), Civic Skills (keterampilan Kewarganegaraan), dan Civic Disposition (watak-watak Kewarganegaraan)". Branson (1998:23) menegaskan bahwa "civic disposition mengisyaratkan pada karakter publik mau- 
pun privat yang penting bagi pemeliharaan dan pengembangan demokrasi konstitusional". Watak kewarganegaraan sebagaimana kecakapan kewarganegaraan, berkembang secara perlahan sebagai akibat dari apa yang telah dipelajari dan dialami oleh seseorang di rumah, sekolah, komunitas, dan organisasi-organisasi civil society.

Pengalaman-pengalaman

demikian hendaknya membangkitkan pemahaman bahwasanya demokrasi mensyaratkan adanya pemerintahan mandiri yang bertanggung jawab dari tiap individu. Karakter privat seperti bertanggung jawab moral, disiplin diri dan penghargaan terhadap harkat dan martabat manusia dari setiap individu adalah wajib. Karakter publik juga tidak kalah penting, kepedulian sebagai warga Negara, kesopanan, mengindahkan aturan main (rule of law), berfikir kritis, dan kemauan untuk mendengar, bernegosiasi dan berkompromi merupakan karakter yang sangat diperlukan agar demokrasi berjalan sukses.

Secara singkat karakter publik dan privat itu dapat dideskripsikan sebagai berikut Branson (1998:23-25).

a. Menjadi anggota masyarakat yang indevenden.

b. Memenuhi tanggung jawab personal kewarganegaraan di bidang ekonomi dan politik.

c. Menghormati harkat dan martabat kemanusiaan tiap individu.

d. Berpartisipasi dalam urusan-urusan kewarganegaraan secara efektif dan bijaksana.

e. Mengembangkan berfungsinya demokrasi konstitusional secara sehat.

Pemahaman terhadap gagasan diatas khususnya menghormati harkat dan martabat kemanusiaan tiap individu sesuai dengan sila kemanusiaan yang adil dan beradab. Sebagai seorang mahasiswa keperawatan harus mengakui persamaan derajat persamaan hak dan persamaan kewajiban antara sesama manusia, saling mencintai sesama manusia, mengembangkan sikap tenggang rasa, tidak semena-mena terhadap orang lain, menjunjung tinggi nilai kemanusiaan, gemar melakukan kegiatan kemanusiaan, berani membela kebenaran dan keadilan dalam menjalankan pekerjaannya sebagai seorang tenaga kesehatan.

Watak atau karakter kewarganegaraan (civic disposition) merupakan dimensi yang paling substantif dan esensial dalam mata pelajaran Pendidikan Kewarganegaraan. Dimensi watak atau karakter dipandang sebagai "muara" dari kedua dimensi lainnya yaitu visi, misi, dan tujuan mata pelajaran Pendidikan Kewarganegaraan, karakteristik mata pelajaran Pendidikan Kewarganegaran ditandai dengan penekanan dimensi watak, karakter, sikap dan hal-hal lain yang bersifat afektif.

Selanjutnya seorang warga negara diharapkan memiliki keterampilan secara intelektual maupun secara partisipatif dalam kehidupan berbangsa dan bernegara. Pada akhirnya, pengetahuan dan keterampilannya itu akan membentuk suatu watak atau karakter yang mapan, sehingga menjadi sikap dan kehidupan sehari-sehari. Watak, karakter, sikap atau kebiasaan hidup sehari-hari mencerminkan warga Negara yang baik itu misalnya sikap religious, toleran, jujur, adil, demokratis, menghargai perbedaan, menghormati hukum, menghormati hak orang lain, memiliki semangat kebangsaan yang kuat memiliki rasa kesetiakawanan sosial dan lain-lain.

\section{Pendidikan Kewarganegaraan untuk Perguruan Tinggi}

Pendidikan kewarganegaraan (Civic Education) sebagai salah satu kajian bidang sosial dan kenegaraan yang memiliki peranan yang sangat esensial dalam meningkatkan kualitas manusia. Somantri (2001:166) mengartikan Pendidikan Kewarganegaraan sebagai berikut: Usaha sadar yang dilakukan secara ilmiah dan psikologis untuk memberikan kemudahan belajar kepada peserta didik agar terjadi internalisasi moral pancasila dan pengetahuan kewarganegaraan untuk melandasi tujuan pendidikan nasional, yang diwujudkan dalam integritas pribadi dan perilaku sehari hari. Pendapat David Kerr dalam Winataputra dan Budimansyah (2007:4), menjelaskan bahwa: Citizenship or Civics Education is construed broadly to encompass the preparation of young people for their and responsibilities as citizens and, in particular, the role of education 
(through schooling, teaching and learning) in that preparatory process.

Berdasarkan pendapat tersebut, melalui Pendidikan Kewarganegaraan mahasiswa sebagai generasi muda dipersiapkan untuk mengambil peran dan tanggung jawabnya sebagai warga Negara dan secara khusus, peran pendidikan termasuk didalamnya persekolahan, pengajaran dan belajar dalam proses penyiapan warga Negara tersebut. sejalan dengan hal tersebut, Winataputra (2001: 95) menyatakan bahwa "Pendidikan Kewarganegaraan merupakan suatu tubuh atau sistem pengetahuan yang memiliki (a) antologi civic behavior dan civic culture yang bersifat multidimensional (filosofis, ilmiah, kurikuler dan sosial cultural); (b) epitomologi research, development and diffusion dalam bentuk kajian. PKn menurut NCSS dalam Somantri (2001:284) adalah: "Citizenship education is a prosess compresing all the posiyive influences which are intended to shape a citizen's view this role in society. it comes partly from learning outside the classroom and the home. through Citizenship Education, our youth are helped to gain an understanding of our national ideals, the co on and the process of self government".

Dari definisi tersebut dapat ditarik kesimpulan cakupan PKn lebih luas, karena bahannya selain mencakup program sekolah juga meliputi pengaruh belajar diluar sekolah dan pendidikan di rumah. Selanjutnya, PKn digunakan untuk membentuk generasi muda memperoleh pemahaman cita- cita nasional atau tujuan negara dan dapat mengambil keputusan keputusan yang bertanggung jawab dalam menyelesaikan masalah pribadi, masyarakat dan negara.

\section{Landasan Pembelajaran Nilai Kemanusiaan dalam Pendidikan Kewarganegaraan}

Secara yuridis-formal pendidikan nilai, norma dan moral di Indonesia dilaksanakan melalui pendidikan kewarganegaraan yang berlandaskan pada Undang-Undang Dasar Republik Indonnesia Tahun 1945 (UUD RI 1945) sebagai landasan konstitusional, UndangUndang No. 20 Tahun 2003 tentang Sistem Pendidikan Nasional (Sisdiknas) sebagai landasan operasional, dan Peraturan Menteri
Nomor 22 Tahun 2006 tentang Standar Isi (SI) dan Nomor 23 Tahum 2006 tentang Standar Kompetensi Lulusan (SKL) sebagai landasan kurikuler. Sejalan dengan Kebijakan Departemen Pendidikan Nasional melalui Badan Standar Nasional Pendidikan (BSNP), maka kurikulum pendidikan kewarganegaraan untuk lingkungan lembaga pendidikan formal dilaksanakan dengan berpedoman pada Kurikulum Tingkat Satuan Pendidikan (KTSP). UUD 1945 sebagai landasan konstitusional pada bagian Pembukaan alinea keempat memberikan dasar pemikiran tentang tujun negara.

Salah satu tujuan negara tersebut dapat dikemukakan dari pernyataan "mencerdaskan kehidupan bangsa". Apabila dikaji, maka tiga kata ini mengandung makna yang cukup dalam. Mencerdaskan kehidupan bangsa mengandung pesan pentingnya pendidikan bagi seluruh anak bangsa. Dalam kehidupan berkewarganegaraan, pernyataan ini memberikan pesan kepada para penyelenggara negara dan segenap rakyat agar memiliki kemampuan dalam berpikir, bersikap, dan berprilaku secara cerdas baik dalam proses pemecahan masalah maupun pengambilan keputusan kenegaraan, kebangsaan, dan kemasyarakatan.

UU Nomor 20/2003 tentang Sisdiknas sebagi landasan operasional penuh dengan pesan yang terkait dengan pendidikan kewarganegaraan. Pada Pasal 3 ayat (2) tentang fungsi dan tujuan negara dikemukakan bahwa: Pendidikan nasional berfungsi mengembangkan kemampuan dan membentuk watak serta perdaban bangsa yang bermartabat dalam rangka mencerdaskan kehidupan bangsa, bertujuan untuk berkembangnya potensi peserta didik agar menjadi manusia yang beriman dan bertakwa kepada Tuhan Yang Maha Esa, berakhlak mulia, sehat, berilmu, cakap, kreatif, mandiri, dan menjadi warga negara yang demokratis serta bertanggung jawab.

Adanya ketentuan tentang pendidikan kewarganegaraan dalam UU Sisdiknas sebagai mata pelajaran wajib di jenjang pendidikan dasar, menengah, dan perguruan tinggi menunjukkan bahwa mata pelajaran ini menempati kedudukan yang strategis dalam mencapai tujuan pendidikan nasional di negara ini. Adapun arah pengembangannya hendaknya 
difokuskan pada pembentukan peserta didik agar menjadi manusia Indonesia yang memiliki rasa kebangsaan dan cinta tanah air. Berdasarkan ketentuan Undang-undang yang ada disebutkan bahwa penyelenggaraan pendidikan tinggi dilaksanakan secara demokratis, berkeadilan, tidak diskriminatif, menjunjung tinggi: HAM, nilai keagamaan, nilai kultural, dan kemajuan bangsa, sebagai satu kesatuan yang sistemik, diselenggarakan dengan sistem terbuka, multi makna dan dipandang sebagai suatu proses pembudayaan dan pemberdayaan peserta didik yang berlangsung sepanjang hayat. Dengan memperhatikan hal ini, maka selayaknya penyelenggaraan pendidikan saat ini dan ke depan adalah memberi keteladanan, membangun kemauan, mengembangkan kreativitas peserta didik dalam proses pembelajaran.

Hal ini penting dilakukan karena karakteristik masyarakat di masa depan akan sangat berbeda dengan masyarakat saat ini. Setidaknya kondisi masyarakat di masa depan dicirikan dengan religiositas, kepastian hukum, penghargaan pada hak asasi, dan kontak budaya yang tidak dibatasi negara. Implikasi dari hal demikian bagi penyelenggaraan pendidikan adalah perhatian terhadap perubahan tuntutan tersebut terutama dalam pencapaian kompetensi lulusan pada institusi penyelenggara pendidikan.

Penyelenggaraan pendidikan tinggi selayaknya diarahkan pada hal sebagai berikut menurut Asep Mahpudz (dalam blog pribadinya di unduh 20 maret 2014), yaitu "(1) menghasilkan lulusan yang memenuhi tuntutan kompetensi kehidupan masyarakat dalam dinamika global, (2) penyelenggaraan pendidikan yang relevan dengan kebutuhan masyarakat, mengungkap potensi mahasiswa (kepribadian, keilmuan, keterampilan sosial), (3) membangun hubungan antara pendidik dan peserta yang harmonis yang mendasarkan pada hubungan saling membutuhkan".

Pendapat di atas bermaksud bahwa penyelenggaraan pendidikan di perguruan tinggi terdapat mata kuliah yang dikelompokkan dalam mata kuliah pengembangan kepribadian. Apabila kita mengkaji substansi mata kuliah ini, dapat dikemukakan bahwa adanya mata kuliah pengembangan kepribadian, seperti Pendidikan Agama, Pendidikan Pancasila, Pendidikan
Kewarganegaraan memiliki visi dan misi yang diarahkan untuk menjadi sumber nilai dan pedoman bagi penyelenggaraan program studi dalam mengantarkan mahasiswa mengembangkan kepribadiannya. Misi kelompok MPK adalah membantu mahasiswa memantapkan kepribadiannya agar secara konsisten mampu mewujudkan nilai-nilai dasar keagamaan dan kebudayaan, rasa kebangsaan dan cinta tanah air sepanjang hayat dalam menguasai, menerapkan dan mengembangkan ilmu pengetahuan, teknologi dan seni yang dimilikinya dengan rasa tanggung jawab. Dengan demikian diharapkan kompetensi yang dimiliki mahasiswa setelah mengikuti perkuliahan kelompok mata kuliah pengembangan kepribadian di Perguruan Tinggi adalah mampu menerapkan nilai-nilai tersebut dalam kehidupan sehari-hari; memiliki kepribadian yang mantap; berfikir kritis; bersikap rasional, etis, estetis, dan dinamis; berpandangan luas; dan bersikap demokratis .

Visi dan misi penyelenggaraan pendidikan di Perguruan Tinggi yang menekankan pada pengembangan kepribadian mahasiswa, perlu didukung oleh adanya kesepahaman dosen dan pimpinan Perguruan Tinggi dalam mengembangkan kondisi Perguruan Tinggi yang nyaman, aman dan dinamis, terutama dalam mengembangkan nilai-nilai religiusitas, moral, estetika, etika, dalam penyelenggaraan pendidikan untuk mengantarkan mahasiswa mengembangkan kemampuan diri, pemahaman dan penguasaan tentang hakekat kemanusiaan sebagai mahluk individu, mahluk sosial dan mahluk Tuhan.

Pada era globalisasi dewasa ini dan perubahan sosial yang tidak dapat diduga lagi, menimbulkan ketidakpastian dan menyebabkan bergesernya pola kehidupan dan nilai yang dianut masyarakat. Kondisi seperti demikian, menjadi tantangan bagi pelaksanaan pembelajaran Pendidikan Kewarganegaraan. Oleh karena itu, perolehan hasil pendidikan yang didapat peserta didik selayaknya berupa kemampuan yang dapat dikembangkan lebih lanjut dalam kehidupan sosialnya, semakin dibutuhkannya kemampuan beradaptasi pada kehidupan sosial dengan kemampuan yang dimiliki dalam ilmu pengetahuan dan kematangan afeksi secara keseluruhan. Kemam- 
puan untuk mudah beradaptasi dengan situasi dan kondisi yang terus berubah fluktuatif ini akan menjadi tuntutan dari proses pendidikan di jenjang pendidikan tinggi, terutama pelaksanaan pembelajaran Pendidikan Kewarganegaraan.

\section{Nilai Kemanusiaan pada Pembelajaran Pendidikan Kewarganegaraan}

Berdasarkan ketentuan Undang-undang yang ada disebutkan bahwa penyelenggaraan pendidikan tinggi dilaksanakan secara demokratis, berkeadilan, tidak diskriminatif, menjunjung tinggi: HAM, nilai keagamaan, nilai kultural, dan kemajuan bangsa, sebagai satu kesatuan yang sistemik, diselenggarakan dengan sistem terbuka, multi makna dan dipandang sebagai suatu proses pembudayaan dan pemberdayaan mahasiswa yang berlangsung sepanjang hayat. Dengan memperhatikan hal ini, maka selayaknya penyelenggaraan pendidikan saat ini dan ke depan adalah memberi keteladanan, membangun kemauan, mengembangkan kreativitas mahasiswa dalam proses pembelajaran.

Hal ini penting dilakukan karena karakteristik masyarakat di masa depan akan sangat berbeda dengan masyarakat saat ini. Setidaknya kondisi masyarakat di masa depan dicirikan dengan religiositas, kepastian hukum, penghargaan pada hak asasi, dan kontak budaya yang tidak dibatasi negara. Implikasi dari hal demikian bagi penyelenggaraan pendidikan adalah perhatian terhadap perubahan tuntutan tersebut terutama dalam pencapaian kompetensi lulusan pada institusi penyelenggara pendidikan. Dalam Undang - undang yang dimaksud dengan Hak Asasi Manusia dalam UU HAM (2010:3) adalah : "Seperangkat hak yang melekat pada hakikat dan keberadaan manusia sebagai mahluk Tuhan Yang Maha Esa dan merupakan anugrah-Nya yang wajib dihormati, dijunjung tinggi dan dilindungi oleh negara hukum, pemerintahan dan setiap orang demi kehormatan serta perlindungan dan martabat manusia".

Pemahaman dari penjelasan dia atas bahwa hak asasi manusia adalah hak dasar yang dimiliki manusia sejak manusia itu dilahirkan. Hak asasi dapat dirumuskan sebagai hak yang melekat dengan kodrat kita sebagai manusia yang bila tidak ada hak tersebut, mustahil kita dapat hidup sebagai manusia. Hak ini dimiliki oleh manusia semata - mata karena ia manusia, bukan karena pemberian masyarakat atau pemberian negara. Maka hak asasi manusia itu tidak tergantung dari pengakuan manusia lain, masyarakat lain, atau negara lain. Hak asasi diperoleh manusia dari Penciptanya, yaitu Tuhan Yang Maha Esa dan merupakan hak yang tidak dapat diabaikan.

Sebagai manusia, ia makhluk Tuhan yang mempunyai martabat yang tinggi. Hak asasi manusia ada dan melekat pada setiap manusia. Oleh karena itu, bersifat universal, artinya berlaku di mana saja dan untuk siapa saja dan tidak dapat diambil oleh siapapun. Hak ini dibutuhkan manusia selain untuk melindungi diri dan martabat kemanusiaanya juga digunakan sebagai landasan moral dalam bergaul atau berhubungan dengan sesama manusia. Pada setiap hak melekat kewajiban. Karena itu,selain ada hak asasi manusia, ada juga kewajiban asasi manusia, yaitu kewajiban yang harus dilaksanakan demi terlaksana atau tegaknya hak asasi manusia (HAM). Dalam menggunakan Hak Asasi Manusia, kita wajib untuk memperhatikan, menghormati, dan menghargai hak asasi yang juga dimiliki oleh orang lain. Menurut Mertoprawiro dalam Margono, dkk (2002: 60)

Hak Asasi Manusia di Indonesia bersumber dan bermuara pada Pancasila. Yang artinya Hak Asasi Manusia mendapat jaminan kuat dari falsafah bangsa, yakni Pancasila. Bermuara pada Pancasila dimaksudkan bahwa pelaksanaan hak asasi manusia tersebut harus memperhatikan garis-garis yang telah ditentukan dalam ketentuan falsafah Pancasila.

Penjelasan di atas bagi bangsa Indonesia dalam melaksanakan hak asasi manusia bukan berarti melaksanakan dengan sebebas-bebasnya, melainkan harus memperhatikan ketentuanketentuan yang terkandung dalam pandangan hidup bangsa Indonesia, yaitu Pancasila. Hal ini disebabkan pada dasarnya memang tidak ada hak yang dapat dilaksanakan secara multak tanpa memperhatikan hak orang lain. Setiap hak akan dibatasi oleh hak orang lain. Jika dalam melaksanakan hak, kita tidak memperhatikan hak orang lain,maka yang terjadi adalah 
benturan hak atau kepentingan dalam hidup bermasyarakat, berbangsa, dan bernegara. Negara Republik Indonesia mengakui dan menjunjung tinggi hak asasi manusia dan kebebasan dasar manusia sebagai hak yang secara kodrati melekat dan tidak terpisah dari manusia yang harus dilindungi, dihormati, dan ditegakkan demi peningkatan martabat kemanusisan, kesejahteraan, kebahagiaan, dan kecerdasan serta keadilan.

\section{PENUTUP}

Nilai-nilai kemanusiaan diharapkan bisa diterapkan dalam praktek keperawatan dan pelayanan kesehatan bagi calon tenaga medis dalam dunia kerja nantinya. Dalam pembelajaran pendidikan kewarganegaraan khususnya dalam materi hak asasi manusia bisa membangkitan watak - watak mahasiswa yang baik dalam tugas profesinya nanti. Dengan bisa memberi pelayanan yang optimal kepada masyarakat tanpa adanya penyimpanganpenyimpangan ataupun penyalahgunaan ilmuilmu keperawatan dalam hal-hal yang melanggar nilai-nilai kemanusiaan. Perawat merupakan aspek penting dalam pembangunan kesehatan, karena tenaga perawat merupakan jenis tenaga kesehatan terbesar yang dalam kesehariannya selalu berhubungan langsung dengan pasien dan tenaga kesehatan lainnya.

Mahasiswa keperawatan sebagai bagian dari masyarakat mendapatkan pendidikan Kewarganegaraan di Perguruan Tinggi dalam rangka mempersiapkan mereka agar dapat lebih baik ketika menjadi tenaga medis nantinya. Pembinaan mahasiswa perawat sebagai generasi muda Indonesia, agar menjadi warga Negara yang baik dan cerdas ( smart and good citizenship) dalam tugas dan tanggung jawab sebagai tenaga keperawatan di manapun bekerja nanti. Tujuan dari pendidikan kewarganegaraan yang diberikan di Perguruan Tinggi bertujuan untuk mengajarkan mahasiswa untuk berkarakter kuat layaknya sila - sila dalam pancasila yang mengutamakan Tuhan yang Maha Esa dalam bertindak. Pendidikan Kewarganegaraan mengajarkan bagaimana warga negara itu tidak hanya tunduk dan patuh terhadap negara, tetapi juga mengajarkan bagaimana sesungguhnya warga negara itu harus toleransi dan saling menghargai sesama.

\section{DAFTAR PUSTAKA}

Asep Mahpudz, 2013, diakses 20 Maret 2014: http://asepmahpudz.wordpress.com/2014/ 01/30/relevansi-pendidikankewarganegaraan-dalam-pengembangannilai-kebangsaan-dan-soft-skillsmahasiswa-di-perguruan-tinggi.

Branson, M. S., (1998). Center for Civic Education, Washinton DC: The Communitarian Network.

Branson, M.S. (1999). The Role of Civic Education. Calabasas: CCE.

Dwidiyanti, Meidiana, 2008. Keperawatan Dasar. Semarang : Hasani

Margono, dkk. 2002. Pendidikan Pancasila Topik Aktual Kenegaraan dan Kebangsaan. Malang: Universitas Negeri Malang.

Somantri, N. (2001). Menggagas Pembaharuan Pendidikan IPS. Bandung: Rosda Karya dan PPS UPI.

Winataputra, Udin S dan Budimansyah, D. (2012). Pendidikan Kewarganegaraan Dalam Perspektif Internasional (Konteks, Teori, dan Profil Pembelajaran). Bandung. Widya Aksara Press.

Undang-Undang Dasar tahun 1945 amandemen 2002

Undang - Undang HAM, 2010, Visimedia:

Jakarta.

Undang-Undang Nomor 20 Tahun 2003 tentang Sistem Pendidikan Nasional. 2010. Bandung. Fokusmedia.

Undang - Undang No. 20 tahun 2003 tentang sistem Pendidikan Nasional. 